\title{
Historic Gardens and Parks Worldwide and in Greece: Principles of Acknowledgement, Conservation, Restoration and Management
}

\author{
Eleni Athanasiadou ${ }^{1,2}$ \\ 1 Laboratory Teaching Staff, Aristotle University of Thessaloniki, School of Agriculture, \\ Aristotle University Campus, P.O. BOX 281, 54124 Thessaloniki, Greece; lenovio@agro.auth.gr \\ 2 Vice President Communication Panhellenic Association of Landscape Architects, 15127 Attica, Greece
}

Received: 1 July 2019; Accepted: 14 September 2019; Published: 20 September 2019

check for updates

\begin{abstract}
The International Council on Monuments and Sites (ICOMOS) Florence Charter 1981 on Historic Gardens sets the first guidelines for the definition of a historic garden, in which sites such as large parks, whether formal or landscape, are included. Since then, there is a continuous effort worldwide on issues of historic garden acknowledgement, conservation, restoration and management. Countries with garden and park tradition, such as the U.K., USA, France and others, have several sites registered and protected. Furthermore, historic garden and park associations exist in Italy, Spain and Portugal, among other nations. In Greece, there is no specific official policy or association regarding historic parks, gardens or landscapes. Greek law includes historic gardens and parks within the spectrum of works of art, places of outstanding natural beauty and historic places/lands for partial or absolute protection, and, thus, attempts in identifying historic landscapes fall generally in other categories, but law specified for historic gardens. However, in both the Greek ratification of the European Landscape Convention and the European Biodiversity directives, there are aspects one could interpret as very useful for the acknowledgement and policy-making on historic gardens and parks. In this paper, an overview on historic gardens and parks abroad and in Greece is attempted, along with aspects of acknowledgement, protection, conservation, restoration and management. Finally, a first attempt on methodological outlines for the acknowledgement and conservation of historic gardens and parks in Greece is presented.
\end{abstract}

Keywords: historic gardens; historic parks and gardens; historic parks; historic gardens and parks of Greece; landscape architecture; cultural heritage; green cultural heritage; landscape

\section{Introduction}

Gardens and parks are designed landscapes, an expression of human creativity at a moment in time and space, combining nature and art in a sophisticated amalgam. Places of social importance, a scene for political action, a way of implying wealth and power, part of the broader landscape, part of nature. Furthermore, historic gardens and parks are also touristic landscapes with positive economic attributes [1,2]. Countries with garden and park tradition such as the U.K., USA, France and others, have several sites registered and protected. In Greece, there is no policy or law addressing historic gardens or parks as such. Greek law on environmental protection includes historic gardens and parks within the spectrum of works of art, places of outstanding natural beauty and historic places/lands, 
for partial or absolute protection. Their protection falls, if so, only by chance, within the broader concept of the surrounding space of a building or urban space, and although some hard elements may be preserved, plantings are rarely maintained because of lack of strategic intention. In many official legal documents and policies such as the European Landscape Convention (ratified in Greece in 2010) and the European Biodiversity directives 2014, there are aspects one could interpret as very useful for the acknowledgement and policy making of historic gardens, parks and landscapes in Greece. Raising public awareness is an immediate goal that strategic synchronized steps among relative stakeholders could provide. Another long term goal is to build garden, park and overall environmental consciousness and culture.

A first attempt in setting the scene and building a case on historic parks and gardens in Greece, a subject still in its infancy is attempted in this paper. 'Landscapes of Greece' is a complex term, setting the wider frame of an intertwined green infrastructural matrix; its analysis and presentation is not undertaken in this paper. The research is targeted in the first and second scale of landscape architecture-the garden and the park. Thus, the aim of the research article is presenting the case of historic gardens and parks in Greece, these being part of the country's cultural and natural history and heritage, and suggesting ways of aiding their acknowledgement and further management. Methodologically, the paper starts with an examination on the discourse on the subject abroad. Bibliographical research reveals a substantial attempt worldwide to acknowledge the value of alive 'green' design monuments, works of landscape architecture and to protect them from decay and loss. After the first introductory sections, which set the scene for developing a consciousness of the problem, historic garden and park protection, conservation, restoration and management principles and practices are presented from the experience gained worldwide. Finally, steps and a proposed methodology towards the recognition of historic gardens and parks in Greece is given in the final section of the paper.

The IFLA's (International Federation of Landscape Architects) Cultural Landscapes Committee addresses the "safeguarding, protection, conservation and preservation of cultural landscapes" [3]. UNESCO's (United Nations Educational, Scientific and Cultural Organization) document of operational guidelines for the Implementation of the World Heritage Convention, defines as cultural and natural heritage, among others, "sites: works of man or the combined works of nature and of man, and areas including archaeological sites which are of outstanding universal value from the historical, aesthetic, ethnological or anthropological points of view". Furthermore, it defines five types of cultural and natural properties, adopting specific guidelines to facilitate their evaluation for inscription on the World Heritage List: (a) cultural and natural heritage, (b) mixed cultural and natural heritage, (c) cultural landscapes, (d) movable heritage and (e) outstanding universal value. Gardens and parks fall under the category of cultural landscapes and the subcategory designed landscape [4].

The Venice Charter 1964 defines a monument within a wider concept from that of a single architectural work, i.e., an urban or rural setting [5]. Furthermore, it addresses conservation and restoration issues. The Florence Charter of 1981 on Historic Gardens, adopted by the International Council of Monuments and Sites in December 1982 is the first official document on historic gardens. It defines a historic garden as "an architectural and horticultural composition of interest to the public from the historical or artistic point of view" and "an architectural composition whose constituents are primarily vegetal and therefore living"; a historic garden, thus, should be considered a monument and should be preserved in accordance to the Venice Charter guidelines [6]. Within 25 articles, the Florence Charter elaborates on definition and objectives, maintenance, conservation, restoration and reconstruction of a historic garden, legal and administrative protection issues.

Nowadays, in the U.K., USA, France and other countries of the world, several sites are registered and protected. In most countries, the legal framework that supports the actions mentioned above has come after documentation and policy on architectural monuments. As Lambert and Lovie [7] point out, "Historic parks and gardens are latecomers to the feast of heritage legislation and protection", and even in countries with a tradition of historic park and garden preservation such as England, it was 
not until the publication of Miles Hadfield's A History of British Gardening in 1960 that the first official survey was produced. In the U.K., Historic England was established in 1983, a public body responsible for identifying and registering historic places. It includes over 1600 registered gardens, grounds and other planned open spaces, such as town squares and other sites [8]. In 1993, the European Year for the Garden and in 1994 the Conference on Conservation of Historic Gardens were steps towards the recognition of the need of the establishment of historic gardens and their management worldwide. Furthermore, associations such as the American Public Garden Association, networks such as the European Garden Heritage Network (EGHN) and charities such as the Historic Garden Foundation contribute substantially towards acknowledgement, conservation, management and creation of a cultural and a touristic profile worldwide.

In the USA in the year 2000, the National Park Service, ASLA (American Society of Landscape Architects) and the Library of Congress worked together to enable the creation of the Historic American Landscapes Survey (HALS). In 2001, the American Society of Landscape Architects, the National Park Service and the Library of Congress entered into a Memorandum of Understanding (MOU), setting the framework for collaboration, and in 2010, these organizations signed the Tripartite Agreement that made HALS a permanent federal program. According to the ASLA relative website reference, "there is an increased interest on the concept of historic preservation, addressing not only building structures of urban districts, but the historic landscape on which the above have developed" [9]. HALS has developed several initiatives promoting historic garden documentation: liaisons with various universities, internships, annual competitions (i.e., the Holland Prize), the HALS Challenge (which encourages people around the country to complete and submit a short format history for historic landscape(s) of their choice that fit the annual theme) and others [9].

In France, national associations such as the Society for the Protection of Landscapes and the Aesthetics of France and the various regional DRACs (Direction Regionalle des Affaires Culturelles), which refer directly to the Ministry of Culture, provide services for the preservation of park and garden heritage. The Portuguese Association of Landscape Architects (APAP) and the Portuguese Institute of Cultural Heritage celebrated in November 2018, 30 years from the launch of the first Programme of Historic Gardens in Portugal. Furthermore, historic garden and parks associations exist in Italy, Spain and Norway, among other countries. Historic landscape conservation is advanced in Australia [10], yet relatively new is the recording and registration of historic gardens in Norway, which celebrates this year 100 years since the launch of the first academic program of studies in landscape architecture in Europe; it was not until 2006 that the Norwegian Directorate of Cultural Heritage, together with three regional councils, compiled a pilot study to register historic gardens and parks [11]. In Germany, preservation of historic open spaces became a subject of discussion in the 20th century, yet gardens remained in the exclusive authority and care of owners, whether public or private, until the 1920s [12]. Finally, in Turkey there is a tradition in flower cultivation (i.e., tulipomania), ornamental plantings in parks and creation of luscious gardens in palaces acting as touristic attractions, providing partial protection and proper management of garden and park heritage.

Unfortunately, in many countries, including Greece, there is no legal framework on the documentation, restoration and protection of historic gardens or parks. Greece could benefit from the discourse on establishing historic parks and gardens in other countries; reaching not so far, one could easily see that adjacent countries such as Italy, Spain, Portugal and Turkey have taken major steps in supporting a culture, much appreciated by locals and tourists. Although gardens and parks are evidently fewer in Greece compared to other countries, their loss is against the preservation of historic sites and cultural heritage policy, and their protection is imperative. So many have been lost already. They are alive green heritage and part of the country's natural and socio-cultural history and ought to be preserved for future generations. 


\section{Alive Garden Design Monuments, Historic Parks and Gardens of the World}

\subsection{Famous Historic Gardens and Parks Worldwide}

Garden history can be classified in various periods of time and representative examples of each period are luckily inscripted and registered as specimens of alive green heritage. Alive garden design monuments exist today, elaborating in the most vivid way the need to express and act as a repository of the human-nature relationship. Table 1 illustrates achievements in preservation of garden monuments through the history of garden design and landscape architecture, with these acting as a knowledge seed bank for future endeavors and a reference for researchers. Principles of protection, conservation and restoration, definitions and characteristics of the three are presented in the section following.

Just to mention a few of the mesmerizing examples of declared sites as historic gardens worldwide, the Orto Botanico di Padova is the oldest scientific structure to have kept its initial location. A historic garden since 1545, it was added to UNESCO's World Heritage List in 1997. Today, the botanical garden of Padova belongs to a network of international relations, based on a common dialogue coordinated by the Royal Botanical Garden of Edinburgh, to establish guidelines for the protection and development of ancient botanical gardens [13]. Taliesin (1911-1959), the summer home and studio of famous architect Frank Lloyd Wright (1867-1959), is a prime example of late-19th- and early-20th-century Prairie School style, and it comprises 800 acres located in the Driftless Region, southwestern Wisconsin. In 1976, it was designated as a National Historic Landmark. The rolling hills of southwestern Wisconsin guided the positioning and form of the building. Restoration of the designed landscape is an ongoing process, with the first Romeo and Juliet garden reconstruction being complete in 1992. The restoration team uses drawings and documentation, based on the last years of Wright in the properties (1950-1959), to make restoration decisions for the gardens, orchard and vineyard. Additionally, old photos are used to replant the same types of plants and trees in the same or similar locations as they were back in the 1950s. Wright, who championed 'organic architecture', devised many of his most famous works, including Fallingwater and the Guggenheim Museum, in Taliesin [14]. The Donell Garden (1948) at Sonoma Hills, CA, was designed and completed in 1948 by landscape architects Thomas Church and Lawrence Halprin and architect George Rockrise. Presenting abstract forms in harmony and dedicating equal importance to indoor and outdoor space, the garden presented the social need for a space of escape from the rapidly growing California economy and speedy lifestyle, where one could relax, swim, play and spend time with friends and family. The Mediterranean climate and the eight months of California sunshine aided to the aforementioned functional pattern, combined with Church's visit to the Mediterranean during the 1920s and his enthusiasm with the outdoors way of life. The garden is a representative example of the California School in landscape architecture and of the Abstract style of the 1920s, and acts as an arty, aesthetically pleasing and functionally successful outdoors room. It still remains in the hands of the owners, Dewey and Jean Donnell, and presents one of the best preserved examples of its time, but is unfortunately not open to public, except in the allowance of occasional organized visits [15,16]. The Majorelle Garden was created in 1931 in Marrakesh, Morocco, and had a substantial influence on European garden style. It was founded by Jacques Majorelle, a French orientalist artist, and comprises a two and a half acre botanical garden and a Cubist villa by French architect Paul Sinoir. Jaque Majorelle was influenced by the habits of the Berber people in the Atlas Mountains and their use of cobalt blue of outlining window frames and the interior of alcoves. He was passionate about cacti, succulents and palms, and a large collection of them dominates the garden. In 1981, the French fashion designer Yves St Laurent bought the garden. It is classified as an Art Museum Garden and is open to the public [15,17]. 
Table 1. Garden history eras and representative examples of each period, registered as historical gardens or historical places.

\begin{tabular}{|c|c|c|}
\hline Era & $\begin{array}{l}\text { Time/Landscape } \\
\text { Designer/Architect }\end{array}$ & Representative Example(s) \\
\hline $\begin{array}{l}\text { Prehistoric and Ancient Times } \\
\text { Mesopotamia, Egypt, Persia, Greece and Roman } \\
\text { Italy }\end{array}$ & $600000 \mathrm{BC}-$ & Deir el-Bahri secret grove \\
\hline $\begin{array}{l}\text { The Middle Ages } \\
\text { Byzantine gardens (east Europe) and Western } \\
\text { Europe (the medieval cloister garden) }\end{array}$ & 820-830 AD & $\begin{array}{l}\text { Cloister garden Abbey of St. Gall, } \\
\text { Switzerland }\end{array}$ \\
\hline $\begin{array}{l}\text { The Islamic World } \\
\text { Moorish Spain } \\
\text { Ottoman tulipomania }\end{array}$ & 784-987 AD & $\begin{array}{l}\text { The Alhambra Palace gardens } \\
\text { Aynalıkavak Kasrı }\end{array}$ \\
\hline $\begin{array}{l}\text { Renaissance and Baroque } \\
\text { Italian garden villas } \\
\text { French formal style } \\
\text { English naturalistic gardens }\end{array}$ & $\begin{array}{l}1568 \mathrm{AD} \\
1661-1688 \mathrm{AD} \text {, Andre Le Notre } \\
\text { 1741-1780, H Hoare and H. Flitcroft }\end{array}$ & $\begin{array}{l}\text { Villa Lante, Bagnaia, Italy } \\
\text { Versailles Palace gardens, Paris, France } \\
\text { Stourhead, Wiltshire, England (1741-1780) }\end{array}$ \\
\hline $\begin{array}{l}\text { Oriental Gardens } \\
\text { China } \\
\text { Japan }\end{array}$ & $\begin{array}{l}\text { 12th-18th century } \\
\text { late } 15 \text { th century }\end{array}$ & $\begin{array}{l}\text { Wang Shi Yaun Suzhou } \\
\text { Ryoan-ji (end 15th ce.) }\end{array}$ \\
\hline $\begin{array}{l}\text { USA 17th century-early 20th century } \\
\text { Naturalistic gardens the wild, or natural, } \\
\text { garden/English cottage garden }\end{array}$ & 1885, William Robinson & Gravetye Manor \\
\hline American prairie style, USA & 1950s, Jens Jensen & $\begin{array}{l}\text { Garfield Humboldt and Columbus Park } \\
\text { (altered through the years) }\end{array}$ \\
\hline New American Garden, 1975 & $\begin{array}{l}\text { 1997, Wolfgang Oehme, James van } \\
\text { Sweden and Associates }\end{array}$ & $\begin{array}{l}\text { Virginia Avenue gardens for the Federal } \\
\text { Reserve in Washington D.C. }\end{array}$ \\
\hline Art Nouveau/Catalan Modernism & 1900-1914, Antonio Gaudi y Cornet & $\begin{array}{l}\text { Park Güell } \\
\text { UNESCO World Heritage Style }\end{array}$ \\
\hline Impressionism & 1890, Claude Monet & $\begin{array}{l}\text { Giverny, Normandy, France Restored in } \\
1970 \text { by Gerald der Kemp }\end{array}$ \\
\hline Modern Movement & 1936, Fletcher Steel & $\begin{array}{l}\text { Garden of Namkeag, Stockbridge, } \\
\text { Massachusetts } \\
\text { National Historic Landmark since } 1958\end{array}$ \\
\hline $\begin{array}{l}\text { 1930-1960 America } \\
\text { Modern Movement } \\
\text { California School }\end{array}$ & 1948, Thomas D. Church & $\begin{array}{l}\text { Donnell Garden, Sonoma Hills California } \\
\text { (Private, not open to the public, except for } \\
\text { occasional tours) }\end{array}$ \\
\hline $\begin{array}{l}\text { The Modern Gardens by The Harvard Rebels } \\
\text { (graduates of the Department of Landscape } \\
\text { Architecture, Graduate School of Desion. Harvard) }\end{array}$ & 1952-1966, Garret Eckbo & $\begin{array}{l}\text { Aluminum Company of America (ALCOA) } \\
\text { Forecast Garden Los Angeles, CA }\end{array}$ \\
\hline & 1953-1957, Dan Kiley & $\begin{array}{l}\text { Miller Garden, Columbus, Indiana } \\
\text { (1953-1957) } \\
\text { 2000 National Historic Landmark } \\
\text { Ridgewood, New Jersey }\end{array}$ \\
\hline & 1953, James Rose & $\begin{array}{l}1993 \text { James Rose Center for Landscape } \\
\text { Architectural Research and Design. }\end{array}$ \\
\hline $\begin{array}{l}\text { Landscape as art } \\
\text { Modernist tropical gardens }\end{array}$ & 1970s, Roberto Burle Marx & $\begin{array}{l}\text { Copacabana waterfront, Rio de Janeiro } \\
1996 \text { UNESCO World Heritage tentative list }\end{array}$ \\
\hline
\end{tabular}

Many other important individuals, the majority being landscape architects, have designed and created contemporary landscapes of all scales, and of great historic interest and heritage value: Ian McHarg (1920-2001), Jaques Wirtz (1924-), Ian Hamilton Finlay (1925-2006), Dani Karavan (1930-), Wolfgang Oehme (1930-2011) and James van Sweden (1935-) with The New American Garden, Peter Walker (1932-), Laurie D. Olin (1932), Michel Corajoud (1937-2014), Gilles Clément (1934-), Peter Latz (1939-), Topher Delaney, Kathryn Gustafson (1951-) and others. Perhaps particularly worth mentioning is Martha Schwartz (1951-), a landscape architect with a background in arts, who in 1979 created The Bagel Garden, juxtapositioning fine arts and garden design principles, giving another dimension in the concept of gardens-one without plants. The garden of gold bagels and violet glass groundcover precedes the avant-garde Splice Garden of the Whitehead Institute, another garden 'artifact'. In terms of innovation, and as the term historic underlines-the sense of giving value to something worth keeping-Martha Schwartz's gardens are pieces of art, and as such they ought to be preserved. 


\subsection{Historic Gardens and Parks of Greece}

Gardening as an artistic popular culture holds a history of 200 years and is very much established in Northern Europe [19]. Ornamental plantings and gardens decline in numbers as one descends south in Europe, as does the purpose and character of plantings. In northern Europe, the outdoor residential space is usually a garden, with a lawn and ornamental plantings, aided by the climatic conditions and the phenomenon of 'garden culture'. Although in Northern European countries gardens can be created in abundance solely for aesthetical reasons, as one descends south, ornamental gardens for aesthetic pleasure are limited in number, accompanying only owners and buildings of high socio-economic importance. Cities in Greece comprise high storied flats that lack outdoor private and public spaces and ornamental gardens. Parks are rare, and hard surface plazas are popular. One is to meet flower ornamental gardens combined with vegetable gardens in country homes. These gardens are informal and occur spontaneously, altering annual flower arrangements by season and in year.

The etymology of historic gardens and parks is fairly unknown to the Greek public, partially due to lack of formal, designed landscapes. The terms historic garden or park are not recognized, thus not protected by law. Tsalikidis and Tamoutseli [20] were the first to propose a methodology in Greek for historic garden restoration in four stages, based on the work of foreigners such as Lambert and Goodchild [21], and they insisted in management being crucial in the success of any restoration project. Greek law on environmental protection includes gardens and parks within the broader spectrum of works of art, places of outstanding natural beauty, protected landscapes and historic places/lands for partial or absolute protection. The latter is thoroughly analyzed in law 30128/2002 (Official Gazette A 153/2002) For the Protection of Antiquities and Cultural Heritage, where historic lands are defined as non-material cultural goods. UNESCO's treaty of 1972 concerning world cultural and natural heritage was ratified by the Greek law 1126/30-1-1981, listing 'Meteora' and 'The Holly Mountain' as world heritage monuments. For the first time in the environmental law of 1650/1986, one encounters the concept of landscape by definition, separate from that of the environment and the ecosystem. Ten years after its creation, Greece ratified the European landscape convention by the law $3827 / 2000^{1}$; one can see many opportunities within the convention document to make a case on historic gardens. Furthermore, the Greek law of Preservation of Biodiversity 3937/2011 includes, by definition, the term 'protected landscapes,' yet designed gardens, parks and landscapes are not considered as such within the document. Greek historic garden acknowledgement, documentation, protection, restoration and management are terms of a very preliminary stage of mind processing in general.

Yet, some gardens and parks of historic value do exist in Greece, some being protected by law after they have been identified by a different name to fit existing law requirements and not of that of a 'garden' or even a 'park'. The Old Arboriculture Station of Patras is protected by law since 1984, as a work of art. The importance of the garden is mentioned in the protection document, "the building is surrounded by a worth mentioning garden of monumental trees, palms and representative landscape design of the 19th ce." [23]. However, because of the lack of specific guidelines and knowhow of the preservation of the alive green monuments, the garden nowadays is in a terrible condition. Many examples like this are noted where building and garden fall under a unified category of protection-i.e., work of art-and in most cases it seems that protection is entirely restricted to the building and the garden falls in neglect. The National Garden of Athens, on the other hand, is an example worth mentioning of considerable protection and management. Created in the place of the ancient forest of Lycium, the garden was created as an extension of King Othona's and Queen Amalia's Palace between 1839-1840. The garden became public in 1927, covers an area of 154.00 square meters and is protected by law after its characterization as

1 Kyvelou and Gourgiotis [22] elaborate thoroughly on the relation between spatial planning and landscape, relevant policy and the discourse on the ratification of the European Landscape Convention in Greece; the responsibility of the application of the European landscape convention lays in the hands of the spatial planning division of the Ministry of Environment in Greece. 
a historic place [24]. The Children's Garden of Philothei was constructed during 1959-1964 by the Greek architect Dimitris Pikionis (1887-1968), and is protected by law as a work of art and also as a landscape of outstanding natural beauty. The use of plantings and natural building materials such as stone, straw and bamboo wood, combined with Pikionis' exemplary design skills, create an ideal environment for nature's exploitation and journey of the senses. It is a unique example of combined children's playground design principles and design of outer space according to the Greek genious loci. Yet, the preservation of its character is degrading day by day. Playground elements designed by the architect have been damaged and never been replaced. Immediate action is needed to prevent further deterioration. The Municipal Park of Naousa in Northern Greece counts more than 100 years of existence, and is situated at the ridge of the city, looking amphitheatrically over the Edessa-Naousa Kampos, that being its agricultural plain of peach trees. A landscape dominated by big plane trees was used for recreation in the early $19^{\text {th }}$ century. It was later designed following the formal French symmetrical landscape design with parterres de broderie and gravel paths around the 1930s, and it was re-designed following the naturalistic English garden and landscape design principles in 1959 by a Greek landscape designer. The park, which retains its original design with many of the initial plantings, is not acknowledged as historic, yet some protection is granted because of it being adjacent to the bank and riversides of Arapitsa river [25,26], which are protected by law. Finally, the Historic Garden of Villa Ariadni and its surrounding area, in Crete, was characterized under the Greek biodiversity law as a protected landscape. It is the first time the term 'historic garden' is mentioned in a legal document, yet to fit existing legislation, the garden is protected as a cultural landscape. What is special and rather optimistic of this registration is that the legal document refers to the need of a management plan which ought to overlook all procedures of conservation and restoration regarding the plantings [27].

Other important sites to consider are the lost gardens of late 19th to early 20th century. These include the Eclectic Villas of Thessaloniki, the former royal estate Tatoi in Athens, the gardens of the villas at the Kampos of Chios island, municipality parks of more than 60 years of life in various cities in Greece, gardens of Greek churches and monasteries and, finally, private gardens such as the Anatolia College gardens in Thessaloniki and the Achileion garden in Corfu, among others [25].

\section{Garden and Park Protection, Conservation, Restoration and Management. Principles and Practices Abroad and in Greece}

\subsection{The Issue of 'Protection'}

The main purpose of policy, when granted, is to protect the character of the garden that is worth preserving from damaging development [28]. This assumption initiates many questionable matters. Protection is an umbrella term, and incorporates general and specific-to-site issues. Identifying the worthy character and the elements of the garden is a big issue. Protection is granted after the significance of the garden has been proved and as Sales [28] suggests, "significance is defined by distinctiveness, importance, unique quality, comparison value and specific merit". Why protect, what to protect, from what and by whom - these could be a logical sequence of questions. Why and what to protect must be determined after scientific applied research has taken place, as well as evolving participatory procedures and involvement of relevant stakeholders. Protect from what and from whom implies that there are threats that might jeopardize and damage the character of a garden, that other land uses are favored and that there is lack of policy, among other factors. Participation of possible relevant stakeholders will help identify land use conflicts via common analysis methods (i.e., Strengths/Weaknesses/Opportunities/Threats-SWOT), and public participation procedures and planning and design, although laborous, provide a holistic view of what is the best way to go for a location. Protect by whom is a decision that should be considered thoroughly and an interdisciplinary team should be formed to take action. All the above, if they ought to make a first statement for the protection of a garden, should be quantified and qualified. In many cases, the level of damage is such that the garden may not exist anymore; thus, which is the character worth identifying? That which exists in records. In the case of a garden that existed and has gone extinct, it is a straightforward 
decision. If, for some reason, the existing garden of the past proves to be of noticeable value, restoration from scratch is a way to go. Such a case, for example, could be applicable, i.e., in the lost gardens of Eclectic Villas in Thessaloniki, presenting a concept of European landscaping in the southern Balkans in the late $19^{\text {th }}$ century. Twenty villas of that period exist today, representing the cultural diversity of Thessaloniki at that period, yet numerous others existed, and the majority had luscious gardens to exhibit. Nowadays, only trees survive, and those were planted at later times [29].

\subsection{Conservation, Restoration and Management Matters}

As Don (2007) points out, "a historic garden is a still moment in time and man has the desire to touch, smell, and walk through the past via this medium. Gardens that have not been altered in anything but minutest detail over hundreds of years bring the past alive in the most vivid way possible because, unlike a building or a painting, the components are alive only in the intense present" [19]. There is a distinction between conservation and restoration, and conservation projects in gardens and parks should examine thoroughly the importance of the current situation of the garden or park, before returning the landscape to a desirable earlier state. In the case with restoration projects that return a whole site to a known earlier state, as Lambert and Lovie [7] question, the "sacrifice of mature trees alone would be too great" and as "the nature of landscapes is to be in a process of continuous change and growth, and of design responses to those changes, it is generally inappropriate to think of such a return". McHarg [30] notes that "It is important to recognize the realm of life's essential attribute: change that is reflected in form. This exhibits, not simple multiplication, but relative growth of the parts, better described as rhythm than as mere modular increase". That is very much true when it comes to plantings and gardens. There are certainly, in many cases, inconsistencies between the original master plan and planting design that should be examined in each case individually. Furthermore, as Sales [28] points out, "Indeed, in many respects, comprehensive restoration can be the enemy of real conservation, because the process of restoration and recreation in a garden may destroy much of what exists. Before beginning major works on a site, we should be confident that the restoration will be of greater value (i.e., more significant) than that which would be destroyed. More time spent reflecting on this equation between gain and loss would probably result in the number and scope of substantial garden restorations being greatly reduced - no bad thing" and he suggests that similar thinking should be applied for the terms 'addition', 'adaptation', 'development' and 'change of use' and that the major question to ask oneself is 'whether the value of the proposed changes would outweigh the inevitable losses and whether their impact would be permanent or temporary'. Bakirtzi [31] analyzes the management of vegetation on archaeological sites and monuments in Greece, and suggests that when it comes to the management of vegetation there are three possible decisions: (a) to remove vegetation, (b) to maintain and manage vegetation and (c) to import vegetation, which follow stage 1 , preliminary research; stage 2 , existing vegetation survey and stage 3, assessment of existing vegetation [31]. Private properties may harbor many tree specimens that many be forming in recent years part of the historic character of a garden, i.e., tall cypresses stand in the quad style design of Anatolia College private campus in Thessaloniki, Greece, as part of its unique/different character in terms of plantings, from adjacent properties. In other cases, trees might have outgrown the garden and altered its design, dwarfing the designed landscape, such as the eighteenth-century Cedars of Lebanon in Painshill garden, U.K. Still, one of these cedars is considered monumental and the largest cedar of Lebanon in the U.K. A constant love and hate relationship exists between the caretaker-maintenance responsible individual and the planting fabric, as Lambert and Lovey [7] point out, "in the case of landscape, conservation of fabric is a physical impossibility. This makes the distinction between 'maintenance' of fabric and 'restoration' or 'reconstruction' involving new introductions, largely meaningless. The proper care of gardens is an unending and continuous process of adding to and removing fabric." 
Whether restoration, conservation or both is decided, the procedure should be based on scientific, strategically designed methodology. There are four basic steps, presented in Table $2[20,21]$.

Table 2. Garden restoration stages, modified by Lambert and Goodchild, 1991, and Tsalikidis and Tamoutseli, 1998.

\begin{tabular}{|c|c|}
\hline Basic Stage & Actions Involved \\
\hline $\begin{array}{l}\text { Stage } 1 \\
\text { Preliminary study }\end{array}$ & $\begin{array}{l}\text { - Definition issues, searching on the legal framework, bibliography data, setting } \\
\text { basic criteria }\end{array}$ \\
\hline $\begin{array}{l}\text { Stage } 2 \\
\text { Restoration proposal/plan }\end{array}$ & $\begin{array}{l}\text { - Systematic identification of the spatio-temporal change/history: } \\
\text { Creation of a garden file via plans, photos, descriptions, legal frameworks, } \\
\text { literature reviews, etc. } \\
\text { - Identification of the current situation: topographical map, creation of master } \\
\text { plan and planting design, botanical study } \\
\text { - Assessment of the current situation following landscape analysis principles, } \\
\text { i.e., plantings, phytopathology, soils, drainage, fauna, lighting, vies, types of use } \\
\text { in the garden, archaeological interest, socio-cultural impact, etc. }\end{array}$ \\
\hline $\begin{array}{l}\text { Stage } 3 \\
\text { Restoration criteria }\end{array}$ & $\begin{array}{l}\text { - General criteria } \\
\text { - Specific to site criteria } \\
\text { - Criteria in terms of feasibility } \\
\text { - Criteria in relevance to the future usage of the garden }\end{array}$ \\
\hline $\begin{array}{l}\text { Stage } 4 \\
\text { Implementation }\end{array}$ & - Creation, management and future perspective for the garden \\
\hline
\end{tabular}

Historic American Landscapes Survey (HALS) guidelines of heritage documentation programs are representative of the type of procedure one is to follow in the quest of historic garden acknowledgment and register. Typical documentation consists of making use of three types of documentation [9]: (a) interpretive measured drawings and interpretive drawings, (b) large-format black and white photographs and (c) written histories from reliable sources.

Furthermore, on Historic England's register of Parks and Gardens criteria for designating a garden/park as historic include: (a) date and rarity-even sites less than 30 years old that are of outstanding quality and under threat are considered, and (b) further considerations including sites that "were influential in the development of taste, whether through reputation or reference in literature, sites that are representative examples of a style of layout or a type of site, or the work of a designer (amateur or professional) of national importance, sites that have been linked with special historic people of occasions, sites with a strong group value with other heritage assets" [32].

In many cases insisting on the old, this old may be only being appreciated by experts, and may not contribute to a prosperous future of a garden or a park. Young people should be encouraged to visit the park, and if this means replacing the old with some new, i.e., a demolished pergola and rusty sittings with a new contemporary café, it is desirable and beneficial to the overall goal every conservation management plan ought to have, that is, to keep the garden and park alive and interesting to visit.

As with all gardens and designed landscapes, the key to success is not the application of a beautiful graphic design. When the lights of the celebration fade away, i.e., the day a newly restored garden opens to the public, or the day its historic identity is legally acknowledged and guidelines form a policy document, the really important issue rises-that of the continuous effort in maintaining that character, the functionality, the ecological processes and the aesthetics. For this, strategic planning and continuous labor is crucial. A management plan which foresees the implications of changes of the physical and cultural fabric of the garden, along with the interaction with the public within a long time span, is of importance, and the purpose and goals of conservation ought to be clear from the beginning of the endeavor. 


\subsection{Steps and a Proposed Methodology Towards the Recognition of Historic Gardens and Parks in Greece}

The modern Greek state numbers only 200 years from its establishment. Captivity, war and other major socio-economic conflicts, combined with lack of public and private investment on public space planning, design, construction and maintenance, as well as a favoring of technical studies, i.e., pure architecture and city planning over landscape architecture and natural sciences, has led to almost a total lack of discourse on acknowledging and preserving alive green cultural history such as gardens and parks. Despite Greece being a palimpsest of human creativity, a master in the arts and crafts and an amalgam of natural and anthropogenic elements in combined symmetry, it lacks garden culture, and thus substantial steps in the acknowledgement of the value of the few important cases. Added to the lack in policy, in Greece there is no association or charity on historic gardens. Individual attempts to provide some form of acknowledgment and protection are important, such as the Panhellenic Association of Landscape Architects act of creating a working group named 'Historic Gardens, Parks and Landscapes of Greece' in November 2018, targeting increasing visibility on the issues of historic gardens and parks and ultimately some kind of policy commitment.

A proposed methodology on the way to go in terms of aiding acknowledgement of historic gardens, parks and landscapes in Greece could follow the scheme below (Table 3).

Table 3. Methodology outlines for the acknowledgement and conservation of historic gardens, parks and landscapes in Greece.

\begin{tabular}{|c|c|c|}
\hline Getting Started & $\begin{array}{l}\text { Towards Protection, Conservation, } \\
\text { Restoration and Management }\end{array}$ & $\begin{array}{c}\text { Towards Acknowledgement and } \\
\text { Creation of Public } \\
\text { Consciousness }\end{array}$ \\
\hline $\begin{array}{l}\text { Definitions } \\
\text { List of places } \\
\text { Criteria for identification } \\
\text { and registration }\end{array}$ & $\begin{array}{l}\text { Setting conservation goals } \\
\text { Setting restoration goals } \\
\text { Creating strategic } \\
\text { management plans } \\
\text { Creating socio-economic } \\
\text { feasibility studies } \\
\text { Getting grants-in-aids } \\
\text { Informing, sensitizing and } \\
\text { working closely with authorities, } \\
\text { municipalities, the technical and } \\
\text { geotechnical chamber and } \\
\text { relative ministries (of culture, } \\
\text { agriculture, tourism, education) } \\
\text { Targeting for a policy and } \\
\text { legislation commitment } \\
\text { Targeting for official directives } \\
\text { on protection, conservation, } \\
\text { restoration and management }\end{array}$ & $\begin{array}{l}\text { Raising awareness via } \\
\text { marketing, public events, etc. } \\
\text { Creation of associations, } \\
\text { charities and active groups } \\
\text { Getting schools, academia } \\
\text { and museums and other } \\
\text { public bodies involved }\end{array}$ \\
\hline
\end{tabular}

Modified by Athanasiadou and Thymakis, 2018.

\section{Discussion}

Acknowledgement of historic gardens, parks and landscapes in Greece is essential to prevent further loss of the country's cultural heritage. Once faced with thinking of this huge task, one finds oneself in a complex of important issues to deal with. The first romantic thought of keeping the historic garden alive and preserved, which primarily involves the quest of finding those amazing black and white old master plans and photographs, unfolds and evolves in a series of puzzling managerial issues-what is the purpose, the goal of protection? To preserve or to restore? Or both? Where one starts and ends, or are those two just intertwined constantly? How does one come up with the most effective management plan? To cut or not to cut the old tree? With which species should it be replaced, 
if replaced at all? How does one raise public awareness and involve the public? How is the garden kept alive and with a meaningful purpose of existence? What about funding? What about the evolution of the place? Is the idea of keeping the garden still in a moment in time a trap? When should one let go and look into the future? The dilemma is very apparent when dealing with vegetation. If a historic garden is of value due to, for example, the presence of large elderly cypress, what happens when they naturally die? Another important issue is whether private gardens ought to be open to the public and involved in a scheme of rigid restoration, such as with the Donnell Garden, one of the most famous gardens of the world, one that is private and closed to the public. As private gardens are not only vessels of democratic human culture but also of privatization, what should be the criteria for keeping them 'static' spatio-temporally? Yet, around the world, there is a rising interest in the 'open house' phenomenon and thus the open garden type of tourism could be a way to go, with private houses and gardens opening their gates to welcome tourists. Could this be the way ahead to secure grants that are so necessary for historic garden and park sustainability?

All of the above are in a very infant stage in Greece. The first step is the acknowledgement of the importance of conserving historic gardens and parks, as they are part of the country's cultural and natural history. The protection labels of work of art, historic place, landscape of outstanding natural beauty and cultural landscape, although granting theoretically a protection regime, are powerless, since they are vague and do not set guidelines for management. How is possible to protect and manage a historic garden or park when one does not even recognize it as such? In hypothesizing the ways in which to get pragmatic in the protection and management of historic gardens and parks in Greece, a bottom up procedure could be more appropriate in getting acknowledgement and ultimately legal registration. The research group established by the Panhellenic Association of Landscape Architects on 'Historic Gardens, Parks and Landscapes in Greece' in November of 2018 could prove to be crucial; their research findings ought to 'sensitize' and pressure municipalities, the Technical and the Geotechnical Chamber of Greece and then, or parallel, the Ministry of Culture, Ministry of Education, Ministry of Environment and Energy, Ministry of Agricultural Development and Food, Ministry of Tourism, etc., for the release of official documentation on protection and management of historic parks and gardens. The rest ought to follow. Let us be optimistic.

\section{Conclusions}

The creation of gardens depicts throughout the world an anthropogenic expression of recognizing the value of nature, trying to captivate it and incorporate it human habitats. Alive green garden and park culture is part of the broader concept of cultural heritage and, as such, it ought to be protected and enhanced. Lack of garden culture and education leads to everyday degradation and loss of historic parks and gardens in Greece, a concept relatively unknown to the public. It is imperative to take action in two pylons; the first is raising public awareness of the issue. The second is aiming at taking advantage of existing legal documents, and also creating new versions, to secure reduction of further loss and decay and target protection, conservation, restoration and management procedures. This paper is an introduction to the subject. Perhaps the important work of others, such as the results of the very recent working group 'Historic gardens, parks and landscapes in Greece', of the Panhellenic Association of Landscape Architects, could truly lead the way.

Funding: This research received no external funding.

Acknowledgments: Permission to mention the existence of the working group 'Historic Gardens, Parks and Landscapes of Greece' of the Panhellenic Association of Landscape Architects was granted for this paper.

Conflicts of Interest: The author declares no conflict of interest. As founding member and coordinator of the aforementioned working group, the author would like to declare that absolutely no part of the work being carried out within the working group is presented in this paper. 


\section{References and Notes}

1. Consultant, C.A. The economic contribution of historic parks, gardens and designed landscapes: A review of existing data and research and recommendations for future research. Cult. Trends 1999, 9, 27-79. [CrossRef]

2. Čakovská, B. Garden tourism: Reasons for opening private gardens in the UK National Garden Scheme. Curr. Issues Tour. 2018, 21, 1344-1348. [CrossRef]

3. IFLA Cultural Landscapes Committee. Available online: http://www.iflaclc.org/statutes.html (accessed on 20 June 2019).

4. WHC. Operational Guidelines for the Implementation of the World Heritage Convention. 17/01 12 July 2017. Available online: https:/whc.unesco.org/en/guidelines/ (accessed on 20 June 2019).

5. ICOMOS. International Charter for the Conservation and Restoration of Monuments and Sites, (The Venice Charter, 1964). 1965. Available online: https://www.icomos.org/charters/venice_e.pdf (accessed on 24 June 2019).

6. ICOMOS. Historic Gardens (The Florence Charter, 1981). 1982. Available online: https://www.icomos.org/ charters/gardens_e.pdf (accessed on 25 June 2019).

7. Lambert, D.; Lovie, J. All Rosy in the Garden? J. Archit. Conserv. 2006, 12, 83-106. [CrossRef]

8. Historic England, Registered Parks and Gardens. Available online: https://historicengland.org.uk/listing/ what-is-designation/registered-parks-and-gardens/ (accessed on 25 June 2019).

9. American Society of Landscape Architects, Professional Practice, Historic American Landscapes Survey (HALS). Available online: https://www.asla.org/ContentDetail.aspx?id=37490 (accessed on 25 June 2019).

10. Russell, J.A. The Genesis of Historic Conservation in Australia. Landsc. Urban Plan. 1989, 17, 305-312. [CrossRef]

11. Gao, L.; Dierze-Schirdewahn, A. Garden culture as heritage: A pilot study of garden culture conservation based on Norwegian examples. Urban For. Urban Green. 2018, 30, 239-246. [CrossRef]

12. Krosigk, V.K. Preservation and maintenance of historic gardens and parks in West Germany. Landsc. Res. 1987, 12, 18-21. [CrossRef]

13. Orto Botanica Universitá di Padova. Available online: http://www.ortobotanicopd.it/en (accessed on 28 June 2019).

14. Frank Lloyd Wright's Taliesin. Available online: https://www.taliesinpreservation.org (accessed on 25 June 2019).

15. Tsalikidis, I.A.; Bakirtzi, O.C. Landscapes and Gardens of Man. Landscape Architecture from Ancient Years until the 21 Century; Epikentro: Thessaloniki, Greece, 2014; ISBN 978-960-458-208-2. (In Greek)

16. The Cultural Landscapes Foundation. The Donnell Garden. Available online: https:/tclf.org/landscapes/ donnell-garden (accessed on 25 June 2019).

17. The Jardin Majorelle. Available online: https://www.jardinmajorelle.com/en/the-jardin-majorelle $\% \mathrm{E} 2 \% 80 \%$ 8B/ (accessed on 28 June 2019).

18. Jellicoe, G.; Jellicoe, S. The Landscape of Man. Shaping the Environment from Prehistory to Present Day, 1st ed.; Thames and Hudson: London, UK, 1995; ISBN 978-0500278192.

19. Don, M. Around the Worlds in 80 Gardens; BBC: London, UK, 2007.

20. Tsalikidis, I.A.; Tamoutseli, K.C. A methodology of restoration and conservation of historic gardens: Contribution to the protection and conservation of cultural heritage. Ktirio J. 1998, 5-16. (In Greek)

21. Lambert, D.; Goodchild, P. Researching a Garden's History from Documentary and Published Sources; Center for the Conservation of Historic Parks and Gardens, Landscape Design Trust, Surrey: London, UK, 1991.

22. Kyvelou, S.S.; Gourgiotis, A. Landscape as Connecting Link of Nature and Culture: Spatial Planning Policy Implication in Greece. Urban Sci. 2019, 3, 81. [CrossRef]

23. Official Gazette of the Hellenic Republic, 3 May 1984. Paper No. 342; 789/15574. (In Greek)

24. Official Gazette of the Hellenic Republic, 23 March 2011. Paper No. 49; 1139998/2568. (In Greek)

25. Athanasiadou, E.; Thymakis, N. Historic gardens, parks and landscapes in Greece. In Proceedings of the Echopolis 2018, Nature and Culture-Based Strategies and Solutions for Cities an Territories: An Idea Whose Time Has Come! Athens, Greece, 26-28 November 2018.

26. Athanasiadou, E.A.; Babos, N.; Thymakis, N. A15, In Search of Historic Landscapes, Parks and Garden, the Need for the Declararion of the Municipal Park of Naousa Into a Cultural Landscape; Nikiforidis, P., Ed.; Conference Public Space+, Technical Chamber Northern Greece Ianos Publications; Technical Chamber of Greece: Athens, Greece, 2019; pp. 73-76. ISBN 978-618-84274-0-2. (In Greek)

27. Official Gazette of the Hellenic Republic, 6 August 2012, Paper No. 262; 2105. (In Greek)

28. Sales, J. Conserving Historic Gardens. J. Archit. Conserv. 2000, 6, 72-84. [CrossRef] 
29. Tsalikidis, I.A. Gardens of Eclectic Villas in Thessaloniki: A Concept of Landscaping in the Southern Balkans in the Late-19th Century. Landsc. J. 1980, 9, 28-41. [CrossRef]

30. Mc Harg, I. Design with Nature; John Wiley and Sons: New York, NY, USA, 1969.

31. Bakirtzi, O.C. The Management of Vegetation at Archaeological Sites an Monuments in Greece. Horticulture and Landscape Architecture; Echedoros: Thessaloniki, Greece, 2014; ISBN 978-618-5149-00-0. (In Greek)

32. Historic England, Register of Parks and Gardens Selection Guide. 2018. Available online: https://historicengland. org.uk/images-books/publications/drpgsg-urban-landscapes/ (accessed on 15 June 2019).

(C) 2019 by the author. Licensee MDPI, Basel, Switzerland. This article is an open access article distributed under the terms and conditions of the Creative Commons Attribution (CC BY) license (http://creativecommons.org/licenses/by/4.0/). 